\title{
Effects of dichloromethane Sarcophyton spp. extract on the lipopolysaccharide-induced expression of nuclear factor-kappa B and inducible nitric oxide synthase in mice
}

\author{
Putut Har Riyadi ${ }^{1,2}$, Didik Wahyudi ${ }^{3}$ and Wendy Alexander Tanod ${ }^{4}$
}

\begin{abstract}
1. Postgraduate Program, Faculty of Fisheries and Marine Science, Brawijaya University, Malang 65145, East Java, Indonesia; 2. Department of Fisheries Post Harvest Technology, Faculty of Fisheries and Marine Science, Diponegoro University, Semarang 50275, Central Java, Indonesia; 3. Department of Biology, Faculty of Science and Technology, State Islamic University of Maulana Malik Ibrahim Malang, Malang 65144, East Java, Indonesia; 4. Department of Fisheries Product Technology, Institute of Fisheries and Marine (Sekolah Tinggi Perikanan dan Kelautan), Palu 94118, Central Sulawesi, Indonesia.

Corresponding author: Wendy Alexander Tanod, e-mail: wendytanod@stplpalu.ac.id

Co-authors: PHR: putut.riyadi@live.undip.ac.id, DW: didik_wahyudi@bio.uin-malang.ac.id

Received: 28-08-2019, Accepted: 29-10-2019, Published online: 03-12-2019
\end{abstract}

doi: www.doi.org/10.14202/vetworld.2019.1897-1902 How to cite this article: Riyadi PH, Wahyudi D, Tanod WA (2019) Effects of dichloromethane Sarcophyton spp. extract on the lipopolysaccharide-induced expression of nuclear factor-kappa $B$ and inducible nitric oxide synthase inmice, Veterinary World, 12(12): 1897-1902.

\begin{abstract}
Background and Aim: The soft coral genus Sarcophyton is a source of cembraneterpen. Sarcophyton is reported to have anti-inflammatory properties, with the ability to reduce the expression of inducible nitric oxide synthase (iNOS) and inhibit nuclear factor-kappa B (NF-kB) activation. This study aimed to investigate the efficacy of dichloromethane (DCM) extracts of soft coral Sarcophyton spp. to inhibit the expression of NF-kB and iNOS induced by lipopolysaccharide (LPS).

Materials and Methods: Crude extracts of Sarcophyton spp. were macerated with DCM (1:3 v/v) for $24 \mathrm{~h}$. Thirty-six $\mathrm{Balb} / \mathrm{c}$ mice were divided into six treatment groups, namely, normal control (without LPS induction), negative control (LPS induction $4 \mathrm{mg} / \mathrm{mL}$ ), comparative control (LPS+Dexamethasone $6 \mathrm{mg} / \mathrm{kg}$ ), and 3 concentration groups extract (LPS+50, 125 , and $250 \mathrm{mg} / \mathrm{kg}$ ). The expression of NF-kB and iNOS was measured in each treatment group.

Results: Flow cytometry analysis showed that the relative number of $\mathrm{NF}_{-} \mathrm{KB}^{+}$cells increased $(18.38 \pm 1.24 \%)$ in LPSinduced mice compared with normal mice $(13.24 \pm 1.15 \%)$. The Sarcophyton spp. DCM extracts decreased the relative number of NF- $-\mathrm{KB}^{+}$cells $(125 \mathrm{mg} / \mathrm{kg}: 13.96 \pm 0.84 \%)$. Immunohistochemical analysis with ImmunoMembrane showed that LPS induction in mice increased iNOS expression when compared to normal mice. The Sarcophyton spp. DCM extracts reduced iNOS expression (especially at $125 \mathrm{mg} / \mathrm{kg}$ ).
\end{abstract}

Conclusion: DCM extracts of Sarcophyton spp. inhibited the activation of NF-kB, resulting in suppressed iNOS expression, which directly inhibits NO production.

Keywords: Alcyoniidae, anti-inflammatory, lipopolysaccharide, nitric oxide, soft coral.

\section{Introduction}

Soft coral is a colony of small animals known as polypoid cnidarians (abbreviated as polyps). Soft coral genus Sarcophyton belongs to the family Alcyoniidae. Sarcophyton is rich in cembraneterpen [1,2]. Sarcophyton has a widened shape and mushroom-like form, with sclerite found in the coenenchymal interior tissue [3].

Inducible nitric oxide synthase (iNOS) is present in various types of cells, in response to stimulation by endotoxins and endogenous pro-inflammatory mediators. Stimulation of pro-inflammatory mediators induces iNOS to produce nitric oxide (NO) [4]. Nuclear factor-kappa B (NF-kB) plays an important

Copyright: Riyadi, et al. Open Access, et al. This article is distributed under the terms of the Creative Commons Attribution 4.0 International License (http://creativecommons.org/licenses/ by/4.0/), which permits unrestricted use, distribution, and reproduction in any medium, provided you give appropriate credit to the original author(s) and the source, provide a link to the Creative Commons license, and indicate if changes were made. The Creative Commons Public Domain Dedication waiver (http:// creativecommons.org/publicdomain/zero/1.0/) applies to the data made available in this article, unless otherwise stated. role in the synthesis of pro-inflammatory cytokines and iNOS expression [5,6]. NF- $\kappa$ B activation increases the expression of pro-inflammatory cytokines, chemokines, and adhesion molecules (ICAM-1, E-selectin, P-selectin, VCAM-1, and HMGB-1) [7,8]. Lipopolysaccharide (LPS) is a glycolipid complex found in the membranes of Gram-negative bacteria and a potent activator of innate immune responses. LPS is the best bacterial immunostimulator to study systemic inflammatory response [9].

Several studies have reported anti-inflammatory properties of Sarcophyton through reduced iNOS expression and inhibited NF- $\kappa$ B activation. Sarcophyton ehrenbergi and Sarcophyton crassocaule have been reported to produce compounds that reduce iNOS expression [10-12]. Furthermore, Sarcophyton pauciplicatum inhibits NF-kB activation [13]. The previous studies have also reported the ability of the dichloromethane (DCM) extract of Sarcophyton spp. (collected from Palu Bay, Central Sulawesi, Indonesia) to inhibit NO release [14]. In addition, soft coral Sarcophyton spp. has the ability to scavenge the free radical DPPH [15]. 
This study aimed to investigate the ability of DCM extracts from Sarcophyton spp. in inhibiting the expression of NF-KB and iNOS induced by LPS in mice.

\section{Materials and Methods}

\section{Ethical approval}

Animal experiments were approved by the Research Ethics Committee, Brawijaya University, Indonesia (Ref. No. 680-Kep-UB).

\section{Soft coral extraction}

Soft coral Sarcophyton spp. was obtained from the Palu Bay, Central Sulawesi, Indonesia, at coordinates 43.3 South Latitude and 119.4 East Longitude. Crude extracts were obtained by macerating a wet sample of Sarcophyton spp. with DCM: methanol (1:1) (Merck) for $48 \mathrm{~h}$. Subsequently, it was filtered and macerated with DCM $(1: 3 \mathrm{v} / \mathrm{v})$ for $24 \mathrm{~h}$ and the solvent was evaporated [11].

\section{Animals and treatment}

Experimental animals consisted of 36 male mice (Mus musculus) Balb/c strain, obtained from the Integrated Research and Testing Laboratory - Unit IV, Gadjah Mada University, Indonesia. Thirty-six Balb/c mice were divided into six treatment groups of six mice each, namely, normal control (without LPS induction), negative control (LPS induction $4 \mathrm{mg} / \mathrm{mL}$ ), comparative control (LPS+Dexamethasone $6 \mathrm{mg} / \mathrm{kg}$ ), extract concentration 1 (LPS $+50 \mathrm{mg} / \mathrm{kg}$ ), extract concentration 2 (LPS $+125 \mathrm{mg} / \mathrm{kg}$ ), and extract concentration 3 (LPS $+250 \mathrm{mg} / \mathrm{kg}$ ). In each treatment group, NF- $\mathrm{kB}$ and iNOS expression were observed.

The selected mice were active, with no fur shedding or bent/deformed limbs. Mice were allowed to adapt for 10 days and placed in groups in sterile plastic cages in animal rooms (Department of Biology, FMIPA, Brawijaya University, Indonesia) maintained

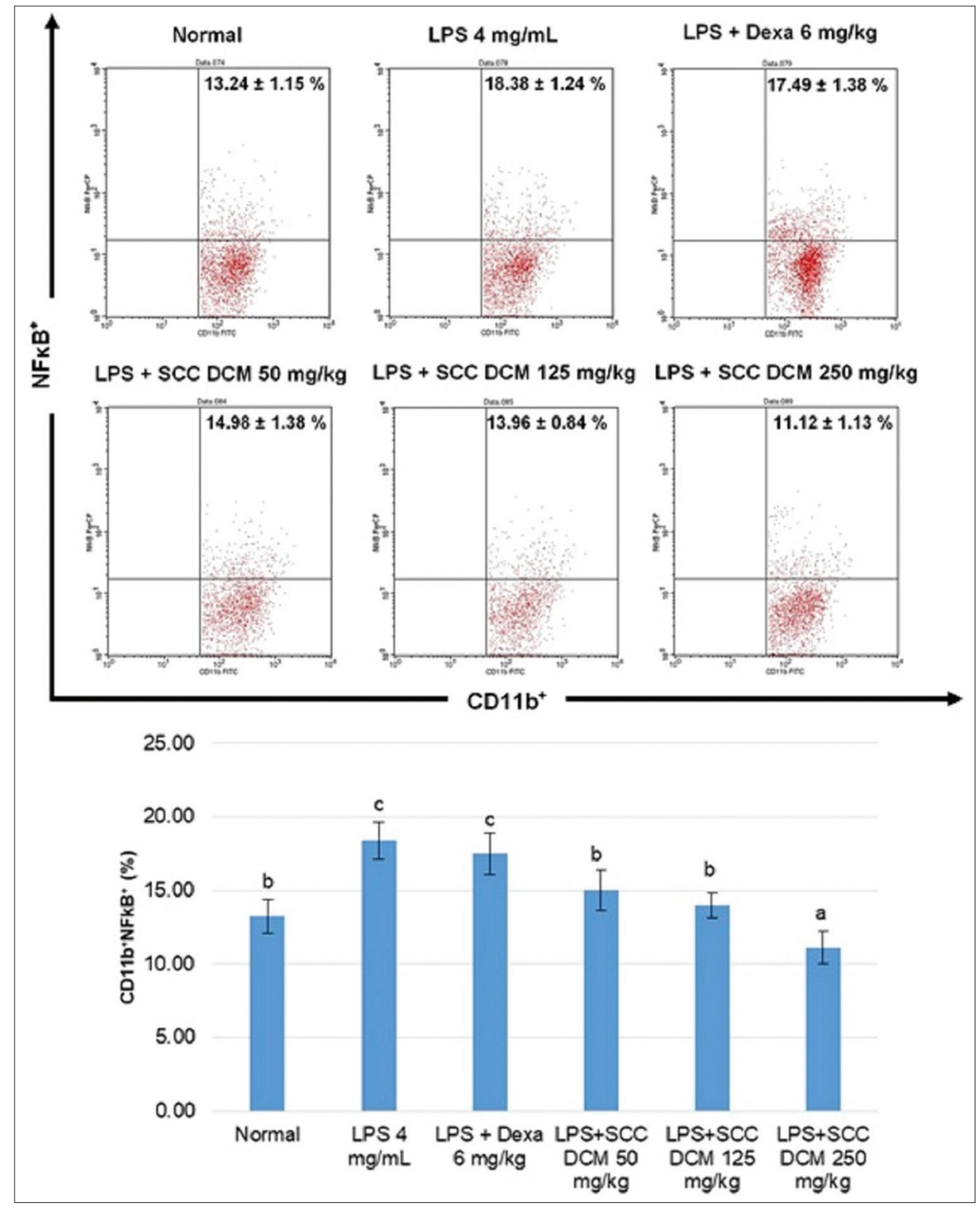

Figure-1: Flow cytometry analysis of nuclear factor-kappa B transcription factors $\left(\mathrm{CD} 11 \mathrm{~b}^{+} \mathrm{NFkB}^{+}\right)$by Sarcophyton spp. dichloromethane extracts. Expressions represented as mean \pm standard deviation ( $n=6$ for each group). Different letters on the figure considered significantly different for each group at $p<0.05$. 


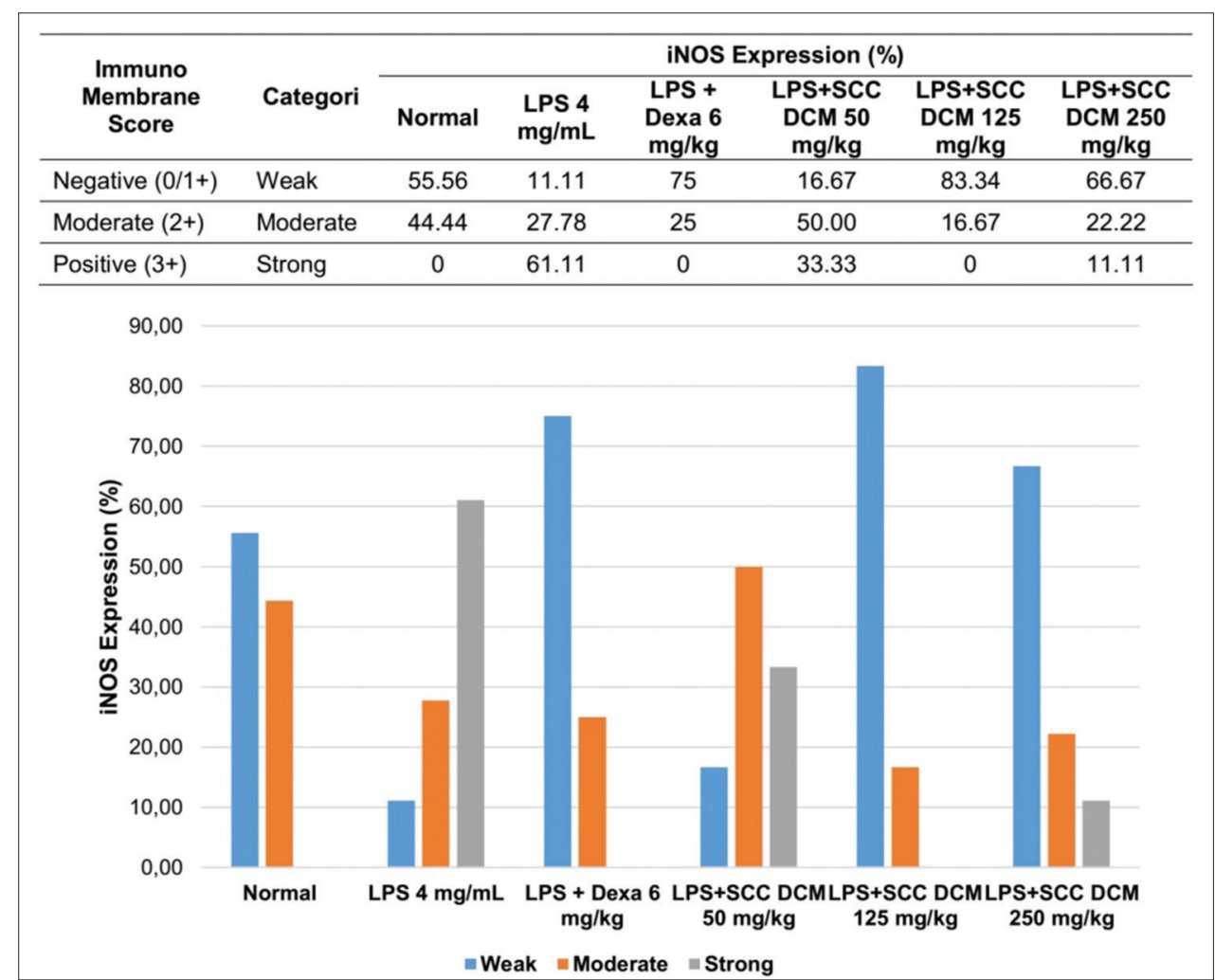

Figure-2: Effects of dichloromethane extract Sarcophyton spp. on inducible nitric oxide synthase expression with ImmunoMembrane analysis.

at a temperature of $24 \pm 2^{\circ} \mathrm{C}$, with $50-60 \%$ humidity and $12 \mathrm{~h}$ of dark/light cycles. The mice were fed a standard diet $(67.2 \%$ carbohydrates, $12.7 \%$ protein, and $5.3 \%$ fat), which were $10 \%$ of the animal body weight and drinking water. Subsequently, mice weighing about 25-30 g were treated with DCM extracts Sarcophyton spp. orally for 14 days. On the $14^{\text {th }}$ day before their sacrifice, mice were induced with LPS (LPS Escherichia coli O111: B4, List Biological Laboratory, Inc.) by administering as much as $10 \mu \mathrm{L}$ of $4 \mathrm{mg} / \mathrm{ml}$ LPS solution intranasally. In normal controls, an equivalent volume of phosphate-buffered saline (PBS) was administered. After 6-8 h of incubation, the mice were sacrificed by cervical dislocation [16].

Evaluation of NF-kB expression with flow cytometry

The spleen was collected and washed twice with sterile PBS. It was placed in a tissue culture dish and crushed apart into a single-cell suspension. A single-cell suspension containing $2-3 \times 10^{6}$ cells was then centrifuged at $2500 \mathrm{rpm}(\mathrm{x} 700 \mathrm{~g})$ for $5 \mathrm{~min}$ at $10^{\circ} \mathrm{C}$ [17]. The supernatant was discarded and the pellet was stained with FITC-conjugated rat antimouse CD11b (Bioss catalog: bs-11127R) against the cell surface marker. It was then incubated in the dark for $20 \mathrm{~min}$ at $4{ }^{\circ} \mathrm{C}$. The previously stained splenocytes were fixed and then permeabilized using a Cytofix/Cytoperm Kit (BD Biosciences, Pharmingen) according to the manufacturer's protocol. The supernatant was discarded and the pellet was stained intracellularly with $\mathrm{PE} / \mathrm{Cy} 5$-conjugated rat anti-mouse NF-kB (Bioss catalog: bs-3543R) followed by incubation in the dark for $20 \mathrm{~min}$ at $4^{\circ} \mathrm{C}$. The staining combination used for flow cytometric detection was $\mathrm{CD} 11 \mathrm{~b}^{+} \mathrm{NF}-\mathrm{\kappa B}^{+}$. The final suspension was analyzed using flow cytometry (BD CellQuest program, San Jose, CA).

\section{Statistical analysis}

The data obtained were subjected to analysis by ANOVA $(p<0.05)$; in the cases of any differences between the treatment groups, a subsequent Tukey's test was performedStatistical Package for Social Science (SPSS) 20.0 for Windows (IBM Corp. NY, USA) was used for data analysis.

\section{Immunohistochemical examination of iNOS expression}

Mice brains were stored in a fixative solution and prepared for immunohistochemistry using a protocol adapted and modified from the previous study [18]. The preparation involved dehydration, clearing, infiltration, paraffin embedding, and sectioning at 4-5 $\mu \mathrm{m}$. A kit obtained from ScyTek Laboratories was used. The slides were dewaxed, rehydrated, and exposed to xylol and ethanol 3 times for $10 \mathrm{~min}$ each. This was followed by peroxidase blocking for $40 \mathrm{~min}$ for image analysis with subsequent rinsing in PBS pH 7.5 (3 times). Next, the sections were incubated overnight at $4^{\circ} \mathrm{C}$ with a primary antibody to NO synthase 2 (Santa Cruz Catalog: SC-7271). The slides were then washed 3 times with PBS pH 7.5 followed by incubation with secondary antibodies with CRF anti-polyvalent biotinylated horseradish peroxidase (HRP) for $1 \mathrm{~h}$. The slides were rinsed 3 times with 
PBS followed by incubation with UltraTek HRP for $40 \mathrm{~min}$. Thereafter, the slides were rinsed with distilled water until the PBS was removed. After that, the slides were incubated with diaminobenzidine (DAB) chromogen in the DAB substrate (high contrast). The target tissue was examined under a microscope until it turned brown. The substrate reaction was stopped by submerging the slide in distilled water for $5 \mathrm{~min}$. The slides were rinsed with distilled water until the substrate was clean. This was followed by counterstaining with Mayer's hematoxylin. The counterstain was rinsed with distilled water until clean. When completely dry, the slides were covered with coverslips. Endothelial cells that express iNOS appeared brown under $400 \times$ with an Olympus BX-51 microscope in six different fields of view. The images obtained were analyzed using ImmunoMembrane software (URL: http://153.1.200.58:8080/ ImmunoMembrane/) and scored as follows: 0/1 for negative/weak expression, $2+$ for moderate expression, and $3+$ for strong expression [19].

\section{Results}

Flow cytometry analysis showed that the relative number of NF- $\mathrm{KB}^{+}$cells was higher in LPS-induced mice compared with normal mice $(\mathrm{p}<0.05)$. The DCM extracts of Sarcophyton spp. reduced the relative number of NF- $\mathrm{KB}^{+}$cells $(\mathrm{p}<0.05)$ (Figures-1 andFigure-2). Although dexamethasone also showed a decrease, it was not statistically significant compared with the mice subjected to induction with $4 \mathrm{mg} / \mathrm{mL}$ LPS.

ImmunoMembrane analysis showed that LPS induction in mice increased iNOS expression compared to normal mice (Figure-2). Treatment with Sarcophyton spp. DCM extracts and dexamethasone reduced iNOS expression (Figure-3). Although iNOS expression increased again in the $250 \mathrm{mg} / \mathrm{kg}$ treatment group, it did not exceed the expression in LPSinduced mice.

\section{Discussion}

LPS is an endotoxin found in Gram-negative bacteria that play a role in forming cell walls and acts as a virulence factor [20-22]. LPS is an innate immune response element and is the sensor with the best characteristics for TLR4-mediated inflammatory response and other important events needed to initiate the innate immune response [23]. LPS stimulation affects the synthesis of interleukin (IL)-1 $\beta$, tumor necrosis factor- $\alpha$, IL-6, and NF-кB ligand receptors $[24,25]$. The transcription factor NF- $\kappa B$ binds to inflammatory mediator protein promoters resulting in the production and secretion of pro-inflammatory cytokines $[26,27]$. The previous study showed that DCM extracts of Sarcophyton spp. inhibited NO production [14]. This inhibition of NO production was presumably achieved by regulating the level of iNOS and its upstream molecules in LPS-induced macrophage cells [28]. The transcription factor NF- $\kappa \mathrm{B}$ promotes

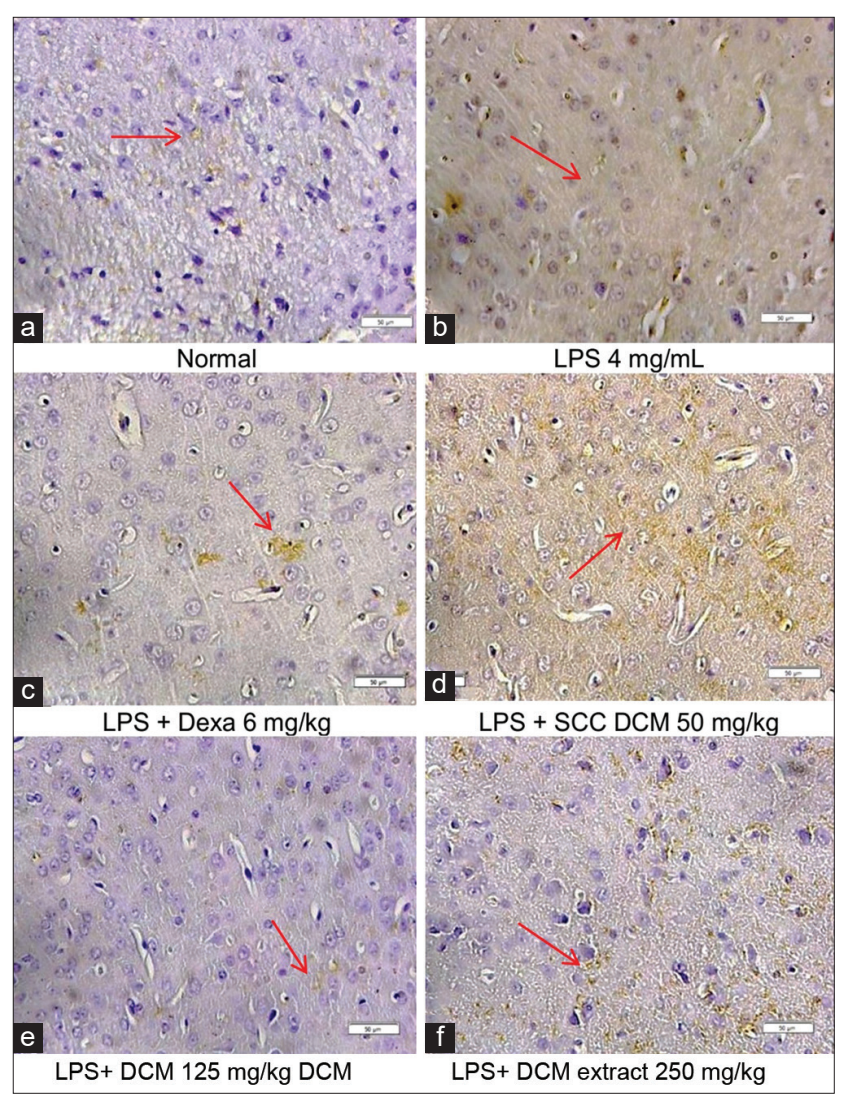

Figure-3: Immunohistochemistry examination showed inducible nitric oxide synthase expression in lipopolysaccharide (LPS)-induced mice. (a) Normal; (b) LPS $4 \mathrm{mg} / \mathrm{mL}$; (c) LPS $+6 \mathrm{mg} / \mathrm{kg}$ dexamethasone; (d) LPS +50 $\mathrm{mg} / \mathrm{kg}$ dichloromethane (DCM) extract Sarcophyton spp.; (e) LPS+125 mg/kg DCM extract Sarcophyton spp.; (f) LPS $+250 \mathrm{mg} / \mathrm{kg}$ DCM extract Sarcophyton spp. 400x; 1 bar $=50 \mu \mathrm{m}$; location of observation: Cerebral cortex; location of expression: Endothelial cells around blood vessels; brown color showed positive reaction.

the expression of iNOS when stimulated by LPS [29]. The results of this study showed that the DCM extracts of Sarcophyton spp. inhibited the activation of NF-kB by decreasing its transcriptional activity and nuclear translocation in LPS-induced macrophage cells.

$\mathrm{NF}-\mathrm{\kappa B}$ reduction occurs through the expression of I $\mathrm{K} B \alpha$ suppressor, which inhibits and reduces the production of pro-inflammatory cytokines. The Sarcophyton spp. DCM extracts showed the ability to reduce the relative number of $\mathrm{NF}-\mathrm{\kappa B}^{+}$cells. It is presumably because the extract can maintain the integrity of I $\mathrm{B} \mathrm{B} \alpha$ so that it can inhibit the translocation of $\mathrm{NF}-\kappa \mathrm{B}$ toward the nucleus of macrophage cells. LPS induction in this study caused a significant increase in NF- $\kappa B$ activation when compared to normal controls (without LPS induction). This trend is consistent with the theory that LPS induction stimulates $\mathrm{NF}-\mathrm{\kappa B}$ activation and expression of pro-inflammatory molecules [5].

iNOS, as one of the three key enzymes that catalyze the production of $\mathrm{NO}$, is an important regulatory molecule in inflammatory response and cancer development [30]. iNOS can be induced after activation by various stimuli, especially pro-inflammatory 
mediators [31]. The NF- $\mathrm{kB}$ signaling pathway plays an important role in regulating the inflammatory response through the transcription of iNOS genes and cytokines [32]. Cells exposed to external pro-inflammatory stimuli such as mitogens, pro-inflammatory cytokines, and LPS cause rapid phosphorylation of I $\mathrm{KB}$ by $\mathrm{I} \kappa \mathrm{B}$ kinase, resulting in nuclear translocation of NF- $\kappa B$ [33]. In the nucleus, NF- $\mathrm{KB}$ induces the transcription of many pro-inflammatory gene targets, including iNOS. iNOS then facilitates the conversion of L-arginine to L-citrulline and large amounts of NO [32]. iNOS gene expression is regulated at the transcriptional level. iNOS induction is primarily dependent on the activity of the transcription factors that interact with cognate cis-acting elements in the iNOS promoter [34-37].

In this study, DCM extracts of Sarcophyton spp. decreased the expression of NF- $\mathrm{kB}$. It was suggested that the suppression of iNOS expression is related to the deactivation of the NF- $\kappa B$ pathway. The results of this study provided a molecular basis for the anti-inflammatory response of Sarcophyton spp. DCM extracts. These extracts have the potential to be used for the discovery/development of pharmaceutical agents for various diseases with an excessive inflammatory response.

\section{Conclusion}

From the results of this study, it can be concluded that the DCM extract of Sarcophyton spp. inhibited the activation of NF-kB, thereby leading to suppress iNOS expression that is directly related to the inhibition of NO production. It can prevent the excessive inflammatory response triggered by LPS induction.

\section{Authors' Contributions}

PHR contributed to the conception, research design, data acquisition, and designed the manuscript. DW did analysis and/or interpretation of data. WAT critically revised and improved the manuscript. All authors read and approved the final manuscript.

\section{Acknowledgments}

We want to acknowledge the Indonesia Endowment Fund for Education (LPDP-BUDI DN), the Ministry of Finance, and the Ministry of Research Technology Higher Education, the Republic of Indonesia for offering a scholarship to the first author for his research with grant no. PRJ-6468/LPDP.3/2016.

\section{Competing Interests} interests.

The authors declare that they have no competing

\section{Publisher's Note}

Veterinary World remains neutral with regard to jurisdictional claims in published institutional affiliation.

\section{References}

1. Kobayashi, J., Ohizumi, Y., Nakamura, H., Yamakado, T., Matsuzaki, T. and Hirata, Y. (1983) Calcium-antagonistic substance from soft coral of the genus Sarcophyton. Experientia, 39(1): 67-69.

2. Blunt, J.W., Carroll, A.R., Copp, B.R., Davis, R.A., Keyzers, R.A. and Prinsep, M.R. (2013) Marine natural products. Nat. Prod. Rep., 30(1): 237-323.

3. Aratake, S., Tomura, T., Saitoh, S., Yokokura, R., Kawanishi, Y., Shinjo, R., Reimer, J.D., Tanaka, J. and Maekawa. H. (2012) Soft coral Sarcophyton (Cnidaria: Anthozoa: Octocorallia) species diversity and chemotypes. PLoS One, 7(1): 1-10.

4. Förstermann, U. and Sessa, W.C. (2012) Nitric oxide synthases: Regulation and function. Eur. Heart J., 33(7): 1-13.

5. Bremner, P. and Heinrich, M. (2002) Natural products as targeted modulators of the nuclear factor-kB pathway. $J$. Pharm. Pharmacol., 54(4): 453-472.

6. Huang, M., Ghai, G. and Ho, C. (2004) Inflammatory process and molecular targets for anti-inflammatory nutraceuticals. Compr. Rev. Food Sci. Food Saf., 3(4): 127-139.

7. Lademarco, M.F., Barks, J.L. and Dean, D.C. (1995) Regulation of vascular cell adhesion molecule-1 expression by IL-4 and TNF-alpha in cultured endothelial cells. J. Clin. Invest., 95(1): 264-271.

8. Tucsek, Z, (2011) Effect of a Red Wine Compound on LPSinduced Inflammatory Processes in vivo and in vitro. [Ph.D Dissertation]. University of Pecs, Hungary.

9. Beutler, B. and Rietschel, E.T. (2003) Innate immune sensing and its roots: The story of endotoxin. Nat. Rev. Immunol., 3(2): 169-176.

10. Cheng, S.Y., Wen, Z.H., Chiou, S.F., Tsai, C.W., Wang S.K., Hsu, C.H., Dai, C.F., Chiang, M.Y., Wang, W.H. and Duh, C.Y. (2009) Ceramide and cerebrosides from the octocoral Sarcophyton ehrenbergi. J. Nat. Prod., 72(3): 465-468.

11. Lin, W.Y., Su, J.H., Lu, Y., Wen, Z.H., Dai, C.F., Kuo, Y.H. and Sheu, J.H. (2010) Cytotoxic and anti-inflammatory cembranoids from the Dongsha Atoll soft coral Sarcophyton crassocaule. Bioorg. Med. Chem., 18(5): 1936-1941.

12. Lin, W.Y., Lu, Y., Su, J.H., Wen, Z.H., Dai, C.F., Kuo, Y.H. and Sheu, J.H. (2014) Bioactive cembranoids, sarcocrassocolides P-R, from the Dongsha Atoll soft coral Sarcophyton crassocaule. Mar. Drugs, 12(2): 840-850.

13. Thao, N.P., Luyen, B.T.T., Sun, Y.N., Song, S.B., Thanh, N.V., Cuong, N.X., Nam, N.H., Kiem, P.V. and

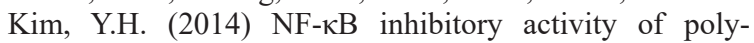
oxygenated steroids from the Vietnamese soft coral Sarcophyton pauciplicatum. Bioorg. Med. Chem. Lett., 24(13): 2834-2838.

14. Tanod, W.A., Yanuhar, U., Maftuch, Putra, M.Y. and Risjani, Y. (2019) Screening of no inhibitor release activity from soft coral extracts origin palu bay, central Sulawesi, Indonesia. Antiinflamm. Antiallergy Agents Med. Chem., 18(2): 126-141.

15. Tanod, W.A., Yanuhar, U., Maftuch, M., Wahyudi, D. and Risjani, Y. (2019) DPPH Scavenging Property of Bioactives from Soft Corals Origin Palu Bay, Central Sulawesi, Indonesia. In: IOP Conference Series: Earth and Environmental Science. Institute of Physics Publishing, Indonesia. p12121.

16. Tian, C., Zhang, P., Yang, J., Zhang, Z., Wang, H., Guo, Y. and Liu, M. (2019) The protective effect of the flavonoid fraction of Abutilon theophrasti medic. Leaves on LPS-induced acute lung injury in mice via the NF-kB and MAPK signaling pathways. Biomed. Pharmacother., 109: 1024-1031.

17. Rifa'i, M. and Widodo, N. (2014) Significance of propolis administration for homeostasis of CD4 + CD25 + immunoregulatory T cells controlling hyperglycemia. Springerplus, 3: $1-8$.

18. Kiernan, J.A. (1990) Histological And Histochemical Methods: Theory and Practice. $2^{\text {nd }}$ ed. Pergamon Press, New York.

19. Rahayu, S., Widhaningrum, S.N., Saadah, M., Soewondo, A., Marhendra A.P.W., Djati, M.S. and Ciptadi, G. (2019) 
The Effects of Powder of Ocimum canum Sims. Leaves on ovary LHR Expression and Serum Estradiol Levels in Premenopausal Rats (Rattus norvegicus). In: AIP Conference Proceedings. p1-5.

20. Seemann, S., Zohles, F. and Lupp, A. (2017) Comprehensive comparison of three different animal models for systemic inflammation. J. Biomed. Sci., 24(1): 1-17.

21. Webb, D.R. (2014) Animal Models of Human Disease: Inflammation. USA: Elsevier Inc.

22. Ridwan, R.D., Sidarningsih, S., Kusumaningsih, T. and Salim, S. (2018) Effect of lipopolysaccharide derived from Surabaya isolates of Actinobacillus actinomycetemcomitans on alveolar bone destruction. Vet. World, 11(2): 161-166.

23. Bhardwaj, R., Verma, R., Deka, D., Dubey, P.P., Arora, J.S., Sethi, R.S., Tolenkhomba, T.C. and Mukhopadhyay, S. (2018) Validation of immunomodulatory effects of lipopolysaccharide through expression profiling of Th1 and Th2 biased genes in Newcastle disease virus vaccinated indigenous chicken. Vet. World, 11(4): 437-445.

24. Shaddox, L.M., Gonçalves, P.F., Vovk, A., Allin, N., Huang, H., Hou, W., Aukhil, I. and Wallet, S.M. (2013) LPS-induced inflammatory response after therapy of aggressive periodontitis. J. Dent. Res., 92(8): 702-708.

25. Kleinert, H., Wallerath, T., Fritz, G., Ihrig-Biedert, I., Rodriguez-Pascual, F., Geller, D.A. and Forstermann, U. (1998) Cytokine induction of no synthase II in human DLD-1 cells: Roles of the JAK-STAT, AP-1 and NF-кBsignaling pathways. Br. J. Pharmacol., 125(1): 193-201.

26. Schottelius, A.J. and Dinter, H. (2006) Cytokines, NF-kB, microenvironment, intestinal inflammation and cancer. Cancer Res. Treat., 130: 67-87.

27. Karin, M. (2006) Nuclear factor- $\kappa B$ in cancer development and progression. Nature, 441(7092): 431-436.

28. Lee, A.K., Sung, S.H., Kim, Y.C. and Kim, S.G. (2003) Inhibition of lipopolysaccharide-inducible nitric oxide synthase, TNF- a and COX-2 expression by sauchinone effects on I- $\mathrm{kBa}$ phosphorylation, $\mathrm{C} / \mathrm{EBP}$ and AP-1 activation. Br. J. Pharmacol., 139(1): 11-20.

29. Xie, Q.W., Kashiwabara, Y. and Nathan, C. (1994) Role of transcription factor NF-kappa B/Rel in induction of nitric oxide synthase. J. Biol. Chem., 269(7): 4705-4708.

30. Baydoun, H.H., Cherian, M.A., Green, P. and Ratner, L. (2015) Inducible nitric oxide synthase mediates DNA double-strand breaks in human T-Cell leukemia virus Type 1-induced leukemia/lymphoma. Retrovirology, 12: $1-16$.

31. Goto, H., Nakamura, T., Shirabe, S., Uekri, Y., Nishiura, Y., Furuya, T., Tsujino, A., Nakane, S., Eguchi, K. and Nagataki, S. (1997) Up-regulation of iNOS mRNA expression and increased production of no in human monoblast cell line, U937 transfected by HTLV-I tax gene. Immunobiology, 197(5): 513-521.

32. Soonthornsit, N., Pitaksutheepong, C., Hemstapat, W., Utaisincharoen, P. and Pitaksuteepong, T. (2017) In vitro anti-inflammatory activity of Morus alba L. Stem extract in LPS-stimulated RAW 264.7 cells. Evid. Based Complement. Altern. Med., 2017: 1-8.

33. Lee, S.H., Kwak, C.H., Lee, S.K., Ha, S.H., Park, J., Chung, T.W., Ha, K.T., Suh, S.J., Chang, Y.C., Chang, H.W., Lee, Y.C., Kang, B.S., Magae, J. and Kim, C.H. (2016) Anti-inflammatory effect of ascochlorin in LPS-stimulated RAW 264.7 macrophage cells is accompanied with the down-regulation of iNOS, COX-2 and proinflammatory cytokines through NF- $\mathrm{BB}, \mathrm{ERK} 1 / 2$, and $\mathrm{p} 38$ signaling pathway. J. Cell Biochem., 117(4): 978-987.

34. Xie, Q.W. (1993) Promoter of the mouse gene encoding calcium-independent nitric oxide synthase confers inducibility by interferon-gamma and bacterial lipopolysaccharide. J. Exp. Med., 177(4): 1779-1784.

35. Marks-Konczalik, J., Chu, S.C. and Moss, J. (1998) Cytokine-mediated transcriptional induction of the human inducible nitric oxide synthase gene requires both activator protein 1 and nuclear factor $\kappa B$-binding sites. J. Biol. Chem., 273(35): 22201-22208.

36. Janssen-Heininger, Y.M., Poynterm, M.E. and Baeuerle, P.A. (2000) Recent advances towards understanding redox mechanisms in the activation of nuclear factor кB. Free Radic. Biol. Med., 28(9): 1317-1327.

37. Vaillancourt, F., Morquette, B., Shi, Q., Fahmi, H., Lavigne, P., Di Battista, J.A., Fernandes, J.C. and Benderdour, M. (2007) Differential regulation of cyclooxygenase-2 and inducible nitric oxide synthase by 4-hydroxynonenal in human osteoarthritic chondrocytes through ATF-2/CREB-1 transactivation and concomitant inhibition of NF-kB signaling cascade. J. Cell Biochem., 100(5): 1217-1231. 